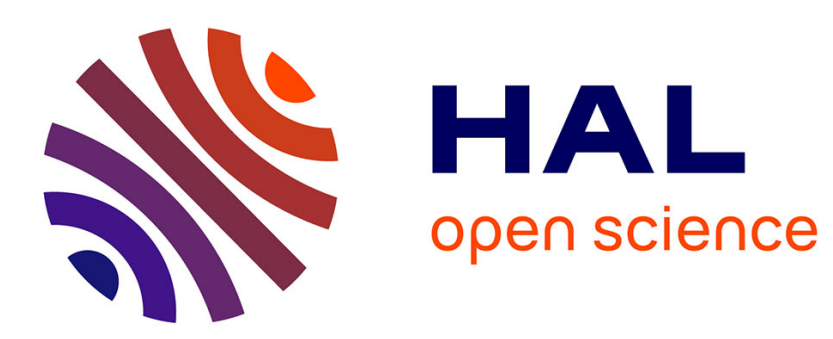

\title{
The new French law on author's rights and related rights in the information society.
}

\author{
Joachim Schöpfel
}

\section{To cite this version:}

Joachim Schöpfel. The new French law on author's rights and related rights in the information society.. Interlending and Document Supply, 2006, 34 (4), 6 p. 10.1108/02641610610714740 . sic_00136830

\section{HAL Id: sic 00136830 \\ https://archivesic.ccsd.cnrs.fr/sic_00136830}

Submitted on 15 Mar 2007

HAL is a multi-disciplinary open access archive for the deposit and dissemination of scientific research documents, whether they are published or not. The documents may come from teaching and research institutions in France or abroad, or from public or private research centers.
L'archive ouverte pluridisciplinaire HAL, est destinée au dépôt et à la diffusion de documents scientifiques de niveau recherche, publiés ou non, émanant des établissements d'enseignement et de recherche français ou étrangers, des laboratoires publics ou privés. 


\title{
The new French law on author's rights and related rights in the information society
}

\section{Joachim Schöpfel}

Head of the E-publishing and Document Supply Department at INIST-CNRS and Lecturer on Scientific Information at the University of Nancy.

\section{Keywords}

Author's rights, EU Copyright Directive, national law, document supply, France

\begin{abstract}
Purpose: France implemented the EU Copyright Directive (EUCD) in June 2006. The paper gives a short description of the content of the new law, of the debate, reactions and possible impact on document supply. Of special interest: the question of private copy and the exception for education and research.
\end{abstract}

Paper type: Viewpoint

\section{Introduction}

The EU directive 2001/29/CE (EUCD) had to be implemented into member states' national laws prior to December 22, 2002. Most of the countries modified their laws on copyright and author's rights between 2003 and 2005 ${ }^{1}$. Spain implemented the directive in June 22, 2006, and after the votes of the National Assembly and Senate June 30, 2006, the French President finally promulgated a new law on the author's rights and related rights in the information society ("Loi $n^{o}$ 2006-961 du $1^{\text {er }}$ aô̂t 2006 relative au droit d'auteur et aux droits voisins dans la société de l'information" called "DADVSI") August 1, 2006 (JO 2006)2.

We have already presented the position of the French government in this journal (Schöpfel 2004, 2005). This paper reprises the history of the new law, its content, some reactions and the possible impact on document supply. It should be stressed that the author is not a lawyer or legal expert, and that the views expressed here do not necessarily reflect those of his employer.

\section{Chronology, lobby and debate}

Preparation of the new law took more than two years. Key dates:

November 2003: The former minister of culture and communication, J.J. Aillagon, presents a first draft that introduces technical restrictions (Digital Rights Management, DRM) and legal sanctions into the existing French law.

\footnotetext{
${ }^{1}$ For background information see Beard et al. (2004), Férnandez-Molina (2003) or Watkins (2003).

${ }^{2}$ See the full text of the new law at http//www.legifrance.gouv.fr/imagesJOE/2006/0803/joe_20060803_0178_0001.pdf
} 
January 2005: The European Court condemns the French state because it fails to implement the EU directive. Another reminder is sent at the end of 2005.

May 2005: C. Vanneste, MP and member of the law commission, submits a report with amendments to the bill.

September 2005: The French Prime Minister, D. de Villepin, goes for unusual emergency procedures (fast-track treatment) for the parliamentary debate.

December 2005: The French parliament (National Assembly) votes against the will of the government by passing two amendments that modify from top to bottom the draft law, legalizing peer-to-peer (P2P) and downloading of internet files if a flat fee been paid ("global licence").

March 2006: First lecture of the law in the National Assembly without the controversial amendments that have been skipped by the government. After 18 sessions and 60 hours of debate, the revised bill is approved by the majority.

May 2006: The second chamber, the Senate, adopts the law with two new amendments: an exception for education and research, and creation of an "authority" for the regulation of the DRM. The obligation for interoperability ${ }^{3}$ disappears.

June 2006: Without a second lecture, the new law is endorsed by the two chambers.

July 2006: The Constitutional Council declares the procedure and law as conforming to the French constitution. After its promulgation by the President, J. Chirac, the DADVSI is published in the Journal Officiel.

Professional and consumer associations lobbied since 2004 against the government's project (see Battisti 2004). More than 7,000 library and information professionals signed a petition that condemned the initial project as "the most restrictive property rights law in Europe" 4 . February 24, 2006, university presidents signed an open letter in favour of the exception for education and research. Another petition launched by the Free Software Foundation (FSF) in 2005 calling for a large public consultation, for protection of open source projects and for equilibrium between author's rights and general interest was signed by 170,000 internet users.

In December 2005, a public survey by the French IFOP institute revealed that two thirds of the population think that those who publish software allowing free downloading of music and videos from internet should be held responsible for the violation of author's rights. At the same time, industry and artists lobbied in favour of a reinforcement of their rights, while the government strongly defended the protection of cultural diversity and artistic creation in France ${ }^{5}$.

The main topics of the long and controversial parliamentary debate were software interoperability, open source software, peer-to-peer transfers, technical measures for the protection of digital content (DRM / TPM), private copy and sanctions of illegal downloading (P2P). The central players were the media, the computer industry and the businesses in digital environment (Apple, Microsoft, Universal, Warner etc) while the needs of libraries, education or research mostly played a secondary role. Overall, the lobbying by economic interests and the political conflicts were closely intertwined in this affair. The debate was largely covered by the written press (Les Echos, Le Monde, Le Figaro, Libération) and the internet ${ }^{6}$.

\footnotetext{
3 "Interoperability is used to describe the capability of different programs to exchange data via a common set of business procedures, and to read and write the same file format and use the same protocols." (Wikipedia)

${ }^{4}$ See http:// www.droitauteur.levillage.org

${ }^{5}$ See the documentation on the Ministry's site at http://www.culture.gouv.fr/culture/actualities/dossiers/davsi/index-droits05.html

${ }^{6} \mathrm{See}$ for instance the synthesis by the Journal du Net at http://www.journaldunet.com/diaporama/0606-dadvsieurope2
} 


\section{Content}

The new DADVSI with its 52 articles goes far beyond the initial draft of 2003. It not only implements the EU directive but tends to create a legal framework for business and internet use in the digital society. What will change?

Sanctions: Illegal action (for instance P2P, manipulation of DRM) will incur graduated sanctions that range from $€ 38$ to $€ 30,000$ or 10 months in prison. Publishing, distributing or promoting software that is "manifestly intended" for unauthorised distribution of copyright works incur a penalty of up to 3 years in prison or a fine of $€ 300,000$.

Exceptions: Exceptions are introduced for education and research, libraries, museums, public archives and disabled persons; fair compensations have to be negotiated. The exception for education and research is not applicable prior to 2009.

Mediation: The law institutes an independent commission ("authority") of mediation and regulation ${ }^{7}$ with legal and technical competence for DRM, interoperability and private copy.

Private copies: The law guarantees the making of private copies but leaves decisions on definition and application to the new authority.

Interoperability: "When I buy a song or video via Internet, I should be able to read it on any machine" declared the Ministry of Culture, R. Donnedieu de Vabres. France is the first country that establishes the right of the internet user to read WMA (Microsoft) or iTunes Music Store (Apple) files on all MP3 devices or computers, independent from the specific technical tools (especially, Apple's iPod). Yet, the new law just claims the interoperability (declaration of intention) but finally does not make it obligatory.

DRM: The law defines the technical measures of digital rights management that protect internet content.

Legal deposit: The law sets up the legal framework for the legal deposit of internet content including software and databases.

Public function: Intellectual property rights of employees of public administrations (civil servants) are defined.

Open access: The government will finance an OA platform for those (especially young) authors and artists who want to freely disseminate their works.

\section{Reactions}

Immediately after the adoption by the two chambers, the opposition (socialist party) introduced a process before the Constitutional Council to invalidate the parliamentary procedure that was rejected. Nevertheless, the socialist party has already announced that they will abolish the law if they win the 2007 elections.

While the industry seems globally satisfied, professionals regret that the amendments undermine the principle of interoperability. "France had the best law on interoperability after the vote of the National Assembly, today it has the most insipid" comments C. Espern from the FSF France (http://eucd.info) and observes that the sanctions of law infringement would not be easy to apply because of the difficulty of technical control. The general sentiment is that the French government capitulated to the media and computer industry in spite of protests from internet users, consumers and professionals (the number of persons that infringe the law on P2P in France is estimated to be about eight million...).

\footnotetext{
${ }^{7}$ Six experts nominated for six years by the government
} 
According to the lawyer B. Lamon, the application of the three-step test contained in TRIPS article 13 and EUCD to make private copies will strongly limit what can be considered as private use. In reality, the problem of private coping, interoperability and DRM, has not been settled by the DADVSI but needs further court decisions and regulation by the new authority.

Reacting to the promulgation of the new law, the journal Etudes Photographiques closed down its free site (on www.revues.org) because of the confusing legal and economic situation of open access to images and texts.

\section{Impact on document supply}

Two aspects, especially are of interest for document supply, the exception for education and research and the concept of private copy.

Exception: In their open letter of February 2006, the university presidents reminded the government that they already pay nearly $€ 3 \mathrm{~m}$ per year for the legal reproduction of protected works ${ }^{8}$. Without the exception for education and research, so their argument, the domination by non-French content and Google would increase. Their intervention was partly successful, and the Senate introduced the exception into the government's project, though restricting it harshly:

The exception excludes educational works (manuals) and "digital editions of written works".

The exception concerns only copies "for illustration" made for students, teachers, and scientists in a non-for-profit context.

The exception is linked to a fair compensation (flat fee) to be negotiated.

Thus, the exception for education and research is limited to non-substantial reproductions from databases and printed works but applies neither to digital libraries nor for other than "illustrative" use - whatever this may be in a scientific context.

Private copy: The DADVSI guarantees the principle of private copying (reproduction of a legally acquired work for personal use) but not the practicalities, for example, defining the number of copies that can be made. It creates confusion between the notion of the private copy and the exclusive copyright of an author. The consumer will continue to pay for private copy when buying blank DVDs or CDs, while at the same time being restricted by DRM. The situation is puzzling: three court decisions (the last in January 2006, UFC-Que Choisir vs. Warner Music/FNAC) give priority to private copy over copy-prevention systems but another court decision (February 2006, UFC-Que Choisir vs. Studio Canal/Universal Pictures, called Mulholland Drive case) has a tendency to exclude DVDs from the private copy exception, considering the private copy NOT an absolute consumers' right. The new law is likely to strengthen this interpretation, linking the private copy to the "normal exploitation" of the protected work and to the "justified economic interests" of the right-holders - a concept to be assessed and negotiated by the new authority.

Document supply: Up to now (August 2006), there has been no direct impact on the activity of the French suppliers (university libraries, ABES, INIST), and we have had no official statement from the Ministry of Education or the French copyright centre CFC. Each institution surely will analyse the new legal environment, if necessary re-negotiate existing agreements and start new negotiations on fair compensation for private copies and the exception for education and research. It is an open question if this will profoundly change the actual situation and the relationship between suppliers, consumers (customers) and publishers.

\footnotetext{
${ }^{8}$ via their agreement with the French Copyright Centre CFC
} 
Anyway, the education for education and research will not apply before January 1, 2009. In the meantime, perhaps we should apply Charles Oppenheim's equation on the risk of copying documents ${ }^{9} \ldots$

\section{And now?}

The new French law is surely not the last but merely one more step in the evolution of author's rights and industry and consumer behaviour in the digital society. The political opposition (but also parts of the conservative majority) have already announced their willingness to revise the DADVSI.

More clarification is to come from court decisions, from the new authority of regulation and from future negotiations between consumer associations, public institutions and rightholders.

Information professionals ("Interassociation archives bibliothèques documentation") continue to lobby at a national and European level for an extension of the exception for education and research to all kinds of works and usages, and call for a large alliance to campaign for this goal

Other European countries, such as Poland, Denmark or Sweden plan to revise their author's rights and to establish the principle of interoperability in their national law.

Five years after the 2001 directive, the European Commission asked the Dutch expert on intellectual property B. Hugenholtz for a careful evaluation of the EUCD and its implementation in the member countries, especially with regard to private copy, fair compensation and DRM measures, and has announced new proposals for the fall of 2006.

The late implementation of the directive by France gives an idea of its limits in the emerging digital environment. Maybe the passionate and controversial French debate finally will have contributed to the revision of the EUCD and to a more equitable legal situation. But what is the meaning of equilibrium in our fast advancing societies?

\section{Bibliography}

Battisti, M. (2004), “Accès à l'information et droit d'auteur: une solution équilibrée est-elle encore possible? Débat de l'interassociation, Paris 22 mars 2004 "Documentaliste, Vol 41, No 2, pp 120-123.

Beard, L., Budd, V., Haller, A., Schuler, M., Silver, I., Wimmers, J. (2004), "Harmonization of Copyright law in the European Community: A comparative overview of the implementation of the Copyright Directive (2001/29/EC) in France, Germany and the United Kingdom". Computer Law Review International, No 2, pp. 33-41.

Férnandez-Molina, J.C. (2003), "Laws against the circumvention of copyright technological protection". Journal of Documentation, Vol 59, No 1, pp. 41-68.

JO (2006), "Loi n ${ }^{\mathrm{O}} 2006-961 \mathrm{du} 1^{\text {er }}$ août 2006 relative au droit d'auteur et aux droits voisins dans la société de l'information". Journal Officiel de la République Française, August 3, 2006.

\footnotetext{
${ }^{9}$ Oppenheim (2005) offers a formula to assess the financial risk involved in undertaking certain actions in an unspecific legal environment with facts open to interpretation. His formula puts together (a) the subjective probability that what is being done is infringement, (b) the chance that the copyright owner will find out, (c) the probability that the copyright owner chooses to take legal action, and (d) the likely damage plus costs that might be awarded against the infringer if the case were to come to Court.
} 
Oppenheim, C. (2005), "Legal issues for information professionals VIII: understanding the recent changes to copyright law". Serials, Vol 18, No 3, pp. 186-191.

Schöpfel, J. (2004), "Transitions - news on the access to digital information in France". Interlending \& Document Supply, Vol 32, No 1, pp. 47-49.

Schöpfel, J. (2005), "Between open access and copyright: document supply in France". Interlending \& Document Supply, Vol 33, No 3, pp. 158-161.

Watkins, J. (2003), "Changes in the UK copyright law: implications for document delivery". Interlending \& Document Supply, Vol 31, No 1, pp. 21-24.

All web sites visited in July and August 2006.

\section{The author}

Joachim Schöpfel is Head of the E-publishing and Document Supply Department at INISTCNRS and Lecturer on Scientific Information at the University of Nancy.

$\underline{\text { schopfel@inist.fr }}$ 